\title{
Analysis of Productive Qualities of Pigs When Including DKB Feed Supplement in the Diet
}

\section{Alexander Chernyshkov, Inna Zasemchuk, and Sergey Semenchenko}

Federal state budgetary educational institution of higher education "Don State Agrarian University"

\section{ORCID:}

Alexander Chernyshkov: http://orcid.org/0000-0001-7116-1897

\section{Abstract}

Improving the efficiency of pig farming requires biologically complete feeding in accordance with the age, physiological and sexual characteristics of animals based on the knowledge of composition and nutritional value. The health and productivity of animals depends on the use of protein, fat, carbohydrates and minerals, and high-quality vitamins. Traditional feed does not provide animals with a sufficient and optimal ratio of minerals and vitamins. One of the factors providing young pigs with these nutrients may be the inclusion of the DKB vitamin-mineral energy supplement in

Corresponding Author: Alexander Chernyshkov donchene@mail.ru

Published: 5 April 2021

Publishing services provided by Knowledge E

(c) Alexander Chernyshkov et al. This article is distributed under the terms of the Commons Attribution License, which permits unrestricted use and redistribution provided that the original author and source are credited.

Selection and Peer-review under the responsibility of the DonAgro Conference Committee.

\section{G OPEN ACCESS} the diet. The article analyzes the influence of DKB on the productivity of young pigs. The aim of the study was to justify an increase in productivity indicators of large white pigs feeding with DKB. In order to trace the impact of DKB on the productivity of pigs, we took into account the change in their live weight. During the experiment (60 days), $54 \mathrm{~kg}$ of the vitamin-mineral complex worth 3300 rubles was spent on the 20 piglets of the experimental group. This entailed an increase in the total costs. The results of the study indicate a positive effect of the additive on the dynamics and growth rate of the piglets of the experimental group and on the cost of feed and nutrients, which favorably affects the profitability and economic efficiency of pork production.

Keywords: DKB vitamin-mineral energy supplement, piglets, live weight, growth dynamics, average daily gain, feed costs, profitability, economic efficiency.

\section{Introduction}

The main task of the agro-industrial complex is to solve the food problem, provide the population with food. One of the main directions is to increase the volume of meat production [1].

Health, productivity and reproductive qualities farm animals are determined by their nutritional status, the degree to which the body is provided with energy and biologically active substances. 
Food deficiency is accompanied by the inability of the protective systems of the body to respond to adverse environmental impacts, which sharply increases the risk of many diseases. This problem can be quickly solved by creating a good forage base, using biologically active feed additives. The main task is to use the entire range of feed and biologically active feed additives as part of animal diets [2-4].

Improving meat quality requires improving feed quality. Only when fully supplied with nutrients does the animal's body display the maximum genetic potential of its productivity.

In the structure of pork production costs, feed costs amount to $60 \%$ or more. Therefore, one of the most likely methods of reducing the production cost is the rational use of available feed resources. It is necessary to use additives that contribute to the maximum extraction of nutrients from the feed [5-9].

The health and productivity of animals depends on the use of protein, fat, carbohydrates and minerals, and high-quality vitamins.

Numerous studies have found that the absence or deficiency of vitamins is always accompanied by metabolic disorders, decreased reproductive abilities, deterioration of the nutritional value of animal products, and a decrease in the natural resistance of animals in all age periods [10-12].

The pork production industry of Rostov Region uses feed mixtures produced at farms and characterized by a low biological value and insufficient vitamin supply [13-15].

If there are no vitamins in the feed rations and in order to prevent the vitamin deficiency, it is recommended to add vitamin-mineral concentrates.

\section{Research Purpose and Tasks.}

The aim of the study was to justify an increase in productivity indicators of large white pigs feeding with "DKB".

The following tasks were set:

- to study the effect of "DKB" on the dynamics of live weight;

- to study the cost of feed for the live weight gain;

- to analyze the economic efficiency of DKB.

\section{Methods}

The research scheme is presented in Table 1. 
Animals of the control group received the main diet, balanced in all nutritional indicators according to the norms of feeding; animals of the experimental group received $45 \mathrm{~g}$ of "DKB".

TABLE 1: Experimental scheme

Group
Control group 1
Experimental group 2

\begin{tabular}{|c|}
\hline Number of animals \\
\hline 20 \\
20
\end{tabular}

\begin{tabular}{|c|}
\hline Live weight \\
\begin{tabular}{|c|}
$16.3 \pm 0.4$ \\
$16.2 \pm 0.2$
\end{tabular} \\
\hline
\end{tabular}

Feeding conditions

Main diet (MD)

$\mathrm{MD}+45 \mathrm{~g} /$ animals DKB

Throughout the experiment, the pigs were in the same conditions. Feeding is carried out two times a day.

The DKB supplement including organic acids is a dense, light-colored liquid with pleasant aroma. It includes glycerin, sorbitol, propylene glycol, L-carnitine, organic propionic and phosphoric acids, vitamins A, D, E, B1, B2, B3, B4, B6, B12, C, calcium chloride, phosphorus, cobalt, manganese, zinc, copper, and sulfur.

\section{Results}

In order to trace the impact of the "DKB" on the productivity of pigs, we took into account the change in their live weight.

The results of control weighing showed that the pigs of the experimental group that received the additive had the highest dynamics of live weight gain (Table 2).

This was characteristic of the entire raising period (60 days). During the scientific and industrial experiment involving the use of "DKB", live weight gain was $27.3 \mathrm{~kg}$, which is $2.9 \mathrm{~kg}$ more than in the control group.

The rate of live weight gain was calculated. During the scientific and production experiment, the average daily live weight gain was $455.0 \mathrm{~g}$, which is $48.3 \mathrm{~g}$ or $11.9 \%$ higher than in group 1.

The average daily live weight gain indicators were stable throughout the entire growth period (60 days). (Table 3)

This indicates that the feed mixture used for the pigs of the experimental group had a better nutritional value due to the use of "DKB".

Based on the results of feed consumed and live weight gain dynamics, the cost of feed was calculated. Piglets of the experimental group spent $433.8 \mathrm{~g}$ of digestible protein per $1 \mathrm{~kg}$ of live weight gain, which is $8.8 \%$ lower than in the control group. (Table 4) 
TABLE 2: Live weight gain dynamics

Indicators
The average live weight, $\mathrm{kg}$ :
- at the beginning of the experiment
- on the $10^{\text {th }}$ day of the experiment
- on the $20^{\text {th }}$ day of the experiment
- on the $30^{\text {th }}$ day of the experiment
- on the $40^{\text {th }}$ day of the experiment
- on the $50^{\text {th }}$ day of the experiment
- on the $60^{\text {th }}$ day of the experiment Gross increase in live
weight
\% to group 1

\begin{tabular}{|c|c|}
\hline \multicolumn{2}{|c|}{ Group } \\
\hline & \\
\hline $16.3 \pm 0.4$ & $16.2 \pm 0.41$ \\
\hline $19.0 \pm 0.38$ & $20.0 \pm 0.43$ \\
\hline $23.6 \pm 0.47$ & $24.1 \pm 0.40$ \\
\hline $27.6 \pm 0.51$ & $28.4 \pm 0.44$ \\
\hline $31.7 \pm 0.65$ & $33.1 \pm 0.57$ \\
\hline $36.2 \pm 0.61$ & $38.1 \pm 0.58$ \\
\hline $40.7 \pm 0.59$ & $43.5 \pm 0.57$ \\
\hline 24.4 & 27.3 \\
\hline 100.0 & 111.9 \\
\hline
\end{tabular}

TABLE 3: The live weight gain rate

Indicators
Average live weight gain, $\mathrm{kg}$
at the beginning of the experiment
-10 th day of the experiment
-20 th day of the experiment
-30 th day of the experiment
-40 th day of the experiment
-50 th day of the experiment
-60 th day of the experiment
Average gain
$\%$ to group 1

\begin{tabular}{|c|c|}
\hline \multicolumn{2}{|c|}{ Group } \\
\hline & \multicolumn{1}{|c|}{ I } \\
\hline & \\
\hline $350.0 \pm 54,8$ & $380.0 \pm 62,3$ \\
\hline $380.0 \pm 63,1$ & $410.0 \pm 49,6$ \\
\hline $400.0 \pm 71,4$ & $430.0 \pm 65,2$ \\
\hline $410.0 \pm 55,8$ & $470.0 \pm 79,1$ \\
\hline $450.0 \pm 69,4$ & $500.0 \pm 49,5$ \\
\hline $450.0 \pm 58,4$ & $540.0 \pm 61,9$ \\
\hline $406.7 \pm 70,2$ & $455.0 \pm 47,3$ \\
\hline 100.0 & 111.9 \\
\hline
\end{tabular}

TABLE 4: Feed consumption per live weight gain

Indicators
Spent on $1 \mathrm{~kg}$ of live weight gain:
- feed units, $\mathrm{kg}$
- \% to group 1
- digestible protein, $\mathrm{g}$
\% to group 1

\begin{tabular}{|c|c|}
\hline \multicolumn{3}{|c}{ Group } \\
\hline I & II \\
\hline 4.15 & 4.01 \\
\hline 100.0 & 96.6 \\
\hline 475.5 & 433.8 \\
\hline 100.0 & 91.2 \\
\hline
\end{tabular}

On average, for each kilogram of live weight gain, 4.01 feed units were used which is $3.45 \%$ lower than in the control group, but there were large differences in protein retention. 
The above results confirm the opinion that the use of "DKB" increases the cost of feed per unit of live weight gain.

In the production of pork, special attention is paid to the cost of production. For this purpose, various methods are used. In the structure of pork production costs, feed accounts for more than $60 \%$. Therefore, it is necessary to use cheaper feed, and feed products and additives must be checked for economic efficiency.

The absolute live weight gain amounted to $455 \mathrm{~kg}$, which is $49 \mathrm{~kg}$ more than in the control group. As a result, the value of products in monetary terms amounted to 49,140 rubles, which is 5,220 rubles. higher than in the control group (Table 5).

During the experiment (60 days), $54 \mathrm{~kg}$ of the vitamin-mineral complex worth 3300 rubles were spent on 20 piglets of the experimental group. This entailed an increase in the total costs.

Profit due to the higher intensity of live weight gain amounted to 11300 rubles, which is 1920.0 rubles higher than in the control group.

TABLE 5: Economic efficiency of DKB

Indicators
Number of animals
Duration, days
Average daily live weight gain, $\mathrm{g}$
Absolute live weight gain by groups, $\mathrm{kg}$
Purchase prices, rub./kg
Cost, rub.
Total expenses, rub.
Profit, rub.
Profitability, \%

\begin{tabular}{|c|c|}
\hline \multicolumn{3}{|c|}{ Group } & \\
\hline 1 & II \\
\hline 20 & 20 \\
\hline 60 & 60 \\
\hline 406.7 & 455.0 \\
\hline 488 & 546.0 \\
\hline 90 & 90 \\
\hline 43920 & 49140 \\
\hline 34540 & 37840 \\
\hline 9380 & 11300 \\
\hline 27.2 & 29.9 \\
\hline
\end{tabular}

In the second experimental group, profitability was higher than in the control one by $2.7 \%$ (29.9\%).

\section{Conclusion}

Thus, the use of DKB in the diet of young pigs of the experimental group at a dose of $45 \mathrm{~g}$ per day increases the economic efficiency and profitability of pork production. 


\section{References}

[1] Smolentsev, S. Y. (2017). The Effect of a New Feed Supplement on Pigs. Actual Issues of Improving the Technology of Production and Processing of Agricultural Products, vol. 19, pp. 229-231.

[2] Dorozhkin, V. I., Pavlenko, G. I. and Pavlova, N. S. (2018). The Study of Biological Effects of Feed Additives based on Enzymes. Russian Journal of Problems of Veterinary Sanitation, Hygiene and Ecology, vol. 3, issue 27, pp. 101-106.

[3] Dobruk, E. A., et al. (2004). The Use of Sapropel in the Protein-Vitamin-Mineral Supplements for Fattening Pigs. Zootechnical Science of Belarus, vol. 39, pp. 214216.

[4] Marusich, A. G. (2019). Efficiency of Pork Production using the Feed Additive "MixOil". Livestock and Veterinary Medicine, vol. 1, pp. 61-65.

[5] Kabanov, A. C. (2017). Efficiency of Feeding Multi-Enzyme Complexes and a Probiotic Preparation in the Diets of Young Pigs. Feeding of Farm Animals and Fodder Production, vol. 12, pp. 37-49.

[6] Barykin, A. A., et al. (2016). Mineral Supplement "Coretron" in the Diets of Young Fattening Pigs. Political Internet Electronic Scientific Journal of the Kuban State Agrarian University, vol. 120, pp. 515-526.

[7] Nekrasov, R. V., et al. (2014). Energy Feed Supplement in the Diets of Fattened Young Pigs. Pig Production, vol. 8, pp. 29-31.

[8] Grigoriev, V. S., Vinichenko, G. V. and Sharymova, N. M. (2015). Mineral Feed Supplement Vodnit in the Diet of Large White Pigs. Bulletin of Samara State Agricultural Academy, vol. 1, pp. 29-33.

[9] Li, P. F., et al. (2011). Effects of Fermented Potato Pulp on Performance, Nutrient Digestibility, Carcass Traits and Plasma Parameters of Growing-Finishing Pigs. AsianAustralas Journal Animal Science., vol. 24, pp. 1456-1463.

[10] Feng, J., et al. (2007). The Effect of Aspergillus Oryzae Fermented Soybean Meal on Growth Performance, Digestibility of Dietary Components and Activities of Intestinal Enzymes in Weaned Piglets. Anim. Feed Science Technology, vol. 134, pp. 295-303.

[11] Hung, A. T. Y., et al. (2008). Effect of Probiotic Combination Fermented Soybean Meal on Growth Performance, Lipid Metabolism and Immunological Response of Growing-Finishing Pigs. Asian Journal Animal Veterinary Advances., vol. 3, pp. 431436. 
[12] Kim, S. W., et al. (2010). Fermented Soybean Meal as a Vegetable Protein Source for Nursery Pigs: I. Effects on Growth Performance of Nursery Pigs. Journal Animal Science., vol. 88, pp. 214-224.

[13] Canibe, N. and Jensen, B. B. (2003). Fermented and Nonfermented Liquid Feed to Growing Pigs: Effect on Aspects of Gastrointestinal Ecology and Growth Performance. Journal Animal Science., vol. 81, pp. 2019-2031.

[14] Ao, X., Meng, Q. W. and Kim, I. H. (2011). Effects of Fermented Red Ginseng Supplementation on Growth Performance, Apparent Nutrient Digestibility, Blood Hematology and Meat Quality in Finishing Pigs. Asian-Australas Journal Animal Science., vol. 24, pp. 525-531.

[15] Ahmed, T., et al. (2016). Effects of Dietary Natural and Fermented Herb Combination on Growth Performance, Carcass Traits and Meat Quality in Grower-Finisher Pigs. Meat Science., vol. 122, pp. 7-15. 